\title{
Transmission of Monetary Policy through the Bank Lending Channel in the Philippines
}

\author{
Maria Josefina Angelica C. Aban
}

\begin{abstract}
This paper empirically tests the presence of a bank lending channel of monetary policy in the Philippines. It aims to demonstrate that bank lending channel is present in the Philippines by showing that loan growth is affected by monetary policy shocks. This study uses quarterly data from 2008-2011 of the country's 35 commercial and universal banks. The banks are segregated according to the size of their assets: $>\mathrm{P} 300 \mathrm{~B}($ large), $\mathrm{P200B}<$ size $<\mathrm{P300B}($ large 1$), \mathrm{P100B}<$ size $<\mathrm{P200B}($ large 2), $\mathrm{P} 50 \mathrm{~B}<$ size $<\mathrm{P} 100 \mathrm{~B}$ (medium1), $\mathrm{P} 25 \mathrm{~B}<$ size $<\mathrm{P} 50 \mathrm{~B}$ (medium 2) and $P<25 B$ (small). Panel ordinary least squares method is used to check the relationship between loan growth and monetary policy. Results show that loan growth of small banks is sensitive to movements in monetary policy, thus providing evidence for a bank lending channel in the Philippines. Increase in policy rates result in a decrease in loan supply of small banks. This paper also presents that bank characteristics, particularly size, can have influence in the existence of the bank lending channel.
\end{abstract}

Index Terms-Bank lending channel, loan supply, monetary policy

\section{INTRODUCTION}

A number of empirical studies have been made on the effects of monetary policy movements on the economy and the mechanisms by which these effects are subsequently transmitted into the real economy (e.g. [1]-[3]). The research proposition on the role that financial intermediaries (i.e. banks and insurance companies) take in the transmission mechanism of monetary policy is that monetary policy stance has a direct effect on the balance sheets of these intermediaries [4]. The banks' role in the transmission mechanism of the monetary policy stance through credit channels has also been a subject of numerous studies.

Two subchannels within the credit channel are suggestive of the role of banks in the transmission of monetary policies. These subchannels are the balance sheet channel or the borrower's net worth channel and the bank lending channel [5]-[7]. The balance sheet channel is the channel where policy can weaken the balance sheet of borrowers that can, in turn, affect their borrowing capacity. The bank lending channel, on the other hand, is evident when tight monetary policy and/or an increase in the issuances of commercial papers by firms are shown to be related to a decrease in loan supply rather than a decline in loan demand [6]. The bank lending channel can only be possible under two conditions: if there are borrowers who are dependent on banks for their loan requirements and if the loan supply of these banks are

Manuscript received November 9, 2012; revised January 19, 2013.

Maria Josefina Angelica Aban is with the University of the Philippines, College of Business Administration, Diliman, Quezon City, Philippines (email: maria_josefina_angelica.aban@up.edu.ph). affected by movements in monetary policy [8]. This paper presents evidence to support the existence of the bank lending channel in the Philippines as characterized by the banks' size. The presence of bank lending channel will be ascertained as a constraint in monetary policy is shown to affect the loan supply level of undercapitalized banks, consequently restraining their loan portfolio growth. Following the papers of [2] and [6], this study categorized banks by the size of their assets (bank size). Reference [6] argued that the "too big to fail" policy justifies the use of the asset size as a proxy for information costs. They suggest that banks with sufficient capitalization can absorb the negative effects of a monetary policy constraint on the growth of their loan portfolio. The hypothesis of this study is that movements in policy rates have an effect on the loan growth of smaller banks, thereby providing evidence for a bank lending channel as a mechanism for the transmission of monetary policy into the economy.

This paper is organized as follows: This section is an overview of the transmission of monetary policy and its relevant channels. The next section reviews the literature that shows empirical evidence of bank credit channels from several studies. Section III presents the theoretical framework that lays the basis for the study. Section IV describes the data and estimation with the results and analysis of the findings. Section $\mathrm{V}$ presents the conclusion and possible extensions to the study.

\section{LITERATURE REVIEW}

At least two aspects are to be considered in evaluating the transmission of monetary policy into the real economy; namely, the transmission of the policy from instruments directly controlled by the central bank to the private sector and the relationship between financial conditions and consumption decisions of the consumers [9]. In the case of central bank policy, the transmission mechanism applies as it affects both bank assets and deposits [7]. The instruments controlled by central bank in relation to the monetary policy transmission are reserve requirements and the interest rate; for the non-financial sector, the variables relevant to the transmission of monetary policy include interest rates on loans, deposits and the exchange rates [9].

Studies by [1], [2], [7] have shown the existence of credit channels by which monetary policy affects the economy. These are the borrower's net worth channel or the balance sheet channel and the credit channel called the bank lending channel [10], [11]. According to [8], the balance sheet channel becomes evident from the asymmetric information between lenders and borrowers on the net worth of the borrowers as presented in their balance sheets. Weakened 
balance sheets resulting from policy movements, increases the risk premium on borrowers; this subsequently make it more difficult for these borrowers to gain access to financing from banks [4]. Constraints on monetary policy can result in an increase in the cost of capital as its tightening consequently affects the financial system's liquidity[8].

For the bank lending channel to be operational (i.e. for monetary policy to have an effect on the economy) there are two conditions that must be met; namely, that there should be borrowers who dependent on the credit facilities provided by banks and that the lending activities of banks are constrained by monetary policy stance [12]. According to [13], "the costs of obtaining information about a firm's (financial) condition are greater for smaller firms, thus small firms find it difficult and more costly to obtain credit. Banks have a comparative advantage over other intermediaries in information processing that enable them to lend to smaller firms at a lower cost." As in most parts of the world, banks are still major sources for financing for the private sector, specifically, for smaller firms. The banks' role then in the transmission of monetary policy becomes evident through the bank lending channel [14].

In the bank lending channel, asymmetric information problems between banks and the provider of funds (depositors) create constraints for these banks to have access to sources of loanable funds other than demand deposits [15]. It will be more difficult and costly for smaller and undercapitalized banks than banks with sufficient capital and with higher liquidity level, to replace loan supply with other sources of funds [8]. If these banks are not able to provide viable alternative sources of loanable funds with the tightening of the monetary policy, they will be pressured to limit their lending activities, thus, transmitting the effect of the policy stance into the economy [16], [17]. References [6] and [15] have provided evidence that bigger banks with sufficient capital and liquidity are more likely to have the sources to cushion the effects of monetary policy tightening. Sources of loanable funds other than demand deposits (e.g. from interbank and financial markets) are available to these larger banks, thus providing them with alternative forms of loan fund supply [16]. With their access to other forms of sources for their loan supply, bigger banks are less likely to restrain on their lending activities as compared to smaller banks [17]. The level of the banks' capital and liquidity remain to be determinants of the banks' ability to transmit policy stance into the real economy [6], [18]. References [14] and [19], have established that capital adequacy of banks is a significant factor in the banks' ability to sustain their lending activities after monetary policy movements. As stated in [19], "lending by banks with low capital has a delayed and then amplified reaction to interest rate shocks, relative to well-capitalized banks". Excess liquidity can likewise be a source of loan supply for banks as it can be an alternative to equity or debt [18]. Reference [15] have presented that banks with higher level of liquidity have exhibited an increase in the growth of their loan portfolio despite of monetary policy tightening.

Several studies on the presence of the lending channel show that the response of loan supply on contractions of monetary policy may depend on certain bank characteristics. Reference [17], in testing for presence of lending channel in Austria, classified the banks by how similar they react to changes in interest rate. Reference [11] as stated in their paper, categorized banks "on the presence or absence of a formal regulatory action, supplemented with information on regulators' CAMELS rating for banks". However, a number of papers have shown that classifying banks according to asset size have confirmed that indeed, the size of the bank's assets has an effect on the bank's loan portfolio growth.

Reference [20] use liquidity as a variable to prove the presence of lending channel for Germany, Belgium and the Netherlands; [8] for Venezuela, [21] for Spain and [2] for the US, use bank size, liquidity and capitalization as their basis for investigating the presence of lending channels. Reference [22] for Australia, use bank size and loans to show the relationship between the banks' credit stability and policy-induced movements in their deposits. The results of their studies are consistent with the hypothesis that the bank size, liquidity and capitalization have a significant effect on the banks' loan growth as monetary policy tightens.

An earlier work by [1] has likewise shown the effect of monetary policy shifts on the banks' loan supply. Their results show a decrease in loans with a lag after an increase in policy rates. However, it cannot be determined whether the decrease is from a decline in loan supply or a decline in loan demand. Reference [15] then pointed out that since market imperfections influence the banks' ability to induce marginal sources of financing, the effect therefore on loan supply may be more evident in smaller banks. Their empirical tests, using bank level data, yield results consistent with their hypothesis. The size of the bank is directly linked to the banks' ability to provide loans but is totally indifferent to loan demand [6].

To represent monetary policy shifts, the variable used by several empirical studies (e.g. [1] and [11]) is the change in federal funds rate. Reference [6] use the change in federal funds rate and the change in an indicator computed by [23] as a proxy for monetary policy shift. According to them, the Bernanke-Milhov indicator is derived "using non-borrowed reserves, total reserves, and other variables such as real GDP, GDP deflator and commodity prices." Numerous studies on the presence of lending channels in several countries (e.g. [3], [8] and [24]) utilize other proxy variables to represent the factors significant to finding evidence of lending channels. The study of [14] on the lending channel in the Philippines points out the significance of bank credit channels in the transmission mechanism of monetary policy. Results of her study show that during inflation targeting years 1999-2002, the interest and exchange rate channels have become more distinct and that, as she states, "bank credit channel matters in transmitting impulses into the real economy". According to [9], liberalization in the financial markets in the Philippines in the 1990's has opened up alternatives to bank lending, resulting in a decrease in the ability of credit to be a channel for monetary policy transmission. However,the author adds, that despite of the decline in corporate borrowings, a steady demand for consumer loans is sufficient to keep the credit channel significant.

In the Philippine setting, the lending channel remains to be the mechanism by which monetary policy stance is transmitted into the economy [9]. The policy interest rates relevant to the transmission are the Bangko Sentral ng Pilipinas (BSP) overnight reverse repurchase rate (ORRP) or the borrowing rate and the overnight repurchase rate (ORP) or the lending rate. Studies by BSP have shown that policy 
rates impact on market interest rates. As BSP policy rates affect the level of liquidity in the system, it then affects the short term market rates which include the 91-days treasury bills and the banks' lending and deposit rates [9]. Policy interest rates impact the real economy as a low policy rate can stimulate consumption and investiment demand [3].

\section{THEORETICAL FRAMEWORK}

The role of banks in the transmission of monetary policy into the real economy has been investigated in numerous papers notably [1], [2] and [7]. The theoretical framework presented in this paper is adapted from the papers of [2], [6] and [18].

The transmission of monetary policy into the economy is dependent on at least two determinants of the bank's loan supply namely, liquidity and capital. The bank's liquidity plays an important role as a determinant of its credit supply. Excess liquidity can be a source of funds to expand the bank's loan portfolio instead of sourcing the funds from debt or equity. A high level of liquidity will result in a decrease in marginal cost of additional credit. Therefore, it is expected that banks with sufficient capitalization or banks that are overcapitalized can very well benefit from its lending operations as it has more funds to lend out. The bank's level of capital, which is a measure of its financial strength, is also a determinant of its credit supply. The size of the bank's loan portfolio is dependent on the level of its capital as well as liquidity as these are the bank's main sources of funds for lending. A monetary policy shock in the form of interest rate increase will decrease bank reserves should the bank opt not to augment its credit supply from additional equity and debt. An increase in interest rates caused by monetary stance may cause depositors to shift their funds from demand deposits (low cost funds) to time deposits (high cost funds) to be able to take advantage of high interest rates. The bank's priority source of loan funds is their reserve deposits, which are basically the demand deposits. These deposits (savings and checking account deposits) are considered low cost funds since these pay very low interest to savings account depositors and pay no interest to checking account depositors. Sourcing credit supply from time deposits will be costly for the banks as this type of deposit pay higher interest to depositors thus giving the banks lower spreads on their lending. Consequently, loan growth of undercapitalized banks and/or banks with low level of liquidity will be more affected by monetary policy shocks. These banks will be constrained to decrease the level of their credit portfolio. The basic concept of the bank lending channel is that specific characteristics of banks affect its ability to cushion the effects of monetary policy shocks on the credit supply of these banks [18]. Restrictive monetary policy may decrease bank reserves thereby driving banks to cut back on their lending activities [17]. Therefore, a tightening of monetary policy in the form of an increase in interest rates may translate to a decrease in loan supply of undercapitalized banks. Hence, banks with sufficient capital and/or excess liquidity will be able to sustain its lending activities despite of monetary policy tightening.

\section{DATA, RESULTS AND ANALYSIS}

This study uses the balance sheets of the 35 universal and commercial banks in the Philippines. The balance sheets are from the Bangko Sentral ng Pilipinas website. Items in the balance sheets relevant to the study are the total assets and total loans. Total assets of the banks serve as a basis for categorizing the banks according to size. The total loans per bank are used to calculate loan growth. Aside from these items, proxy for shifts in the monetary policy is the sum of changes in the overnight reverse repurchase rate $(R)$ while the proxy to reflect the economic condition is real GDP $(\mathrm{Q})$ and the inflation rate $(\mathrm{P})$, defined as the percentage change in the GDP deflator. The study attempts to determine if contractions in policy rates have an effect on the loan growth of banks depending on the bank's characteristics, in this case, the bank's size.

To be able to examine the cross-sectional differences in the loan growth, banks are segregated into six categories according to total asset size (see Table I) : >P 300B (large category), P200B < size < P300B (large 1category), P100B < size < P200B (large 2 category), P50B < size < P100B (medium1 category), $\mathrm{P} 25 \mathrm{~B}<$ size $<\mathrm{P} 50 \mathrm{~B}$ (medium 2 category) and $<$ P25B (small category).

TABLE I: LIST OF PHILIPPINE UNIVERSAL AND COMMERCIAL BANKS USED IN THESTUdy CATEGORIZED BY ASSET SIZE

\begin{tabular}{|c|}
\hline $\begin{array}{c}\text { Large: Size: > Php300B } \\
\text { Banco de Oro Unibank Inc. } \\
\text { Metropolitan Bank and Trust Co. } \\
\text { Bank of the Philippine Islands } \\
\text { Land Bank of the Philippines }\end{array}$ \\
\hline $\begin{array}{c}\text { Large 1: Size: < P300B, > P200B } \\
\text { Rizal Commercial Banking Corp. } \\
\text { Philippine National Bank } \\
\text { Development Bank of the Philippines } \\
\text { China Banking Corp. } \\
\text { Union Bank of the Philippines } \\
\text { Citibank N.A. }\end{array}$ \\
\hline $\begin{array}{c}\text { Large 2: Size: < P200B, > P100B } \\
\text { HongKong Shanghai Banking Corp. Ltd. } \\
\text { United Coconut Planters Bank } \\
\text { Allied Banking Corp. } \\
\text { Security Banking Corp. }\end{array}$ \\
\hline $\begin{array}{c}\text { Medium 1: Size < P100B, > P50B } \\
\text { Philippine Trust Co. } \\
\text { East West Banking Corp. } \\
\text { Philippine Bank of Commerce } \\
\text { Philippine Veterans Bank } \\
\text { Standard Chartered Bank }\end{array}$ \\
\hline $\begin{array}{c}\text { Medium 2: Size, < P50B, > P25B } \\
\text { Asia United Bank } \\
\text { ING Bank } \\
\text { Australia and New Zealand Banking Group Ltd. } \\
\text { JP Morgan Chase Bank } \\
\text { Philippine Bank of Commerce } \\
\text { Mizuho Corporate Bank Ltd. } \\
\text { Bank of Tokyo } \\
\text { BDO Private Bank } \\
\text { Maybank Philippines Inc. }\end{array}$ \\
\hline $\begin{array}{c}\text { Small: Size: < P25B } \\
\text { China Trust Philippines Commercial Banking Corp. } \\
\text { Bank of America NT and SA } \\
\text { Bank of China Ltd. } \\
\text { Mega International Commercial Bank } \\
\text { Korea Exchange Bank } \\
\text { Bangkok Bank Public Co. Ltd. }\end{array}$ \\
\hline
\end{tabular}

Quarterly data from 2008 to 2011 are used. Panel ordinary least squares (OLS) method is utilized to check the relationship between the dependent variable, loan growth and 
the independent variable $\mathrm{R}$, which represents the monetary policy indicator. ORRP is chosen as data on ORP is incomplete. $\mathrm{R}$ is the sum of the first differences of ORRP, ORRP lag (1), ORRP lag (2) and ORRP lag (3).

The loan growth, which is the dependent variable, is computed as follows:

$$
\text { Loan growth }=\log \left(L_{t} / L_{t-1}\right)
$$

where $L_{t}$ is the total loans of each bank

The independent variable, $R$ is computed as follows:

$$
R=\Delta O R R P_{t}+\Delta O R R P_{t-1}+\Delta O R R P_{t-2}+\Delta O R R P_{t-3}
$$

The estimation model is as follows:

$$
\mathrm{d} \log (\text { Loans })=\text { Constant }+a_{1} \mathrm{R}+a_{2} \mathrm{~d} \log (\mathrm{Q})+a_{3} \mathrm{~d} \log (\mathrm{P})
$$

where $Q$ is GDP, $P$ is the GDP deflator, $R$ is defined above and dlog takes the first difference of logarithms of the variables and the a's are the regression coefficients.

In the initial estimates, the growth in deposits and securities were included as independent variables as in [6]. This was done to check if an increase in the banks' deposits can cushion the loan supply from the effects of shifts in monetary policy. However, the securities data of most banks is incomplete; therefore, this variable was excluded in the estimation. Including total deposit growth yielded unsatisfactory results and are not presented in this paper anymore.

Table II(a) presents the estimates of the effects of monetary policy, represented by $R$, on loan growth. Following [6] and as stated previously, $\mathrm{R}$ is measured as the sum of the first difference of the overnight reverse repurchase rate (ORRP) up to the third lag: $R=\Delta O R R P_{t}+\Delta O R R P_{t-1}+$ $\triangle O R R P_{t-2}+\triangle O R R P_{t-3}$.

It is interesting to note that the estimated coefficient of $R$ is negative in all the categories but is statistically significant only for the smallest bank group ( size $<\mathrm{P} 25 \mathrm{~B}$, t-stat $=$ (3.0002)) - a result that more or less conforms with the findings of [6]. As they point out, unlike their results, studies using aggregate data show positive and insignificant effect of monetary policy on loan growth (see [1], [25], [26]).

The results imply that loan supplies of larger banks are insensitive to monetary policy while the loan supply of banks belonging to the smallest category are responsive to changes in monetary policy stance.

The results also show that for small banks, a one percent change in $\mathrm{R}$ results in a decrease of 0.2492 in the growth rate of loans. This is the biggest decrease in loan growth rate compared to the decrease in growth rate of other groups. The effect of shifts in monetary policy on the other size categories is insignificant. Of all the categories, the bank group with the largest asset base (>P300B) shows GDP growth as being significant to loan growth $(\mathrm{t}-\mathrm{stat}=2.9511)$. Table II(b) shows the descriptive statistics of the bank groups in the study.

The findings of this research offer evidence to support the hypothesis of this paper that movements in monetary policy rates are inversely related to loan growth. It shows evidence that a bank lending channel is present in the Philippines and the evidence becomes visible when data is disaggregated according to bank asset size. As shown above, the distributional consequence of monetary policy for the US found in [6] is also shown for the Philippines.

\section{CONCLUSION}

The presence of the lending channel is significant to the transmission of the monetary policy into the economy. Empirical studies categorize banks according to certain characteristics when testing for the existence of these channels. The results of this paper are consistent with the hypothesis that the bank lending channel is evident in banks with smaller assets. As [14] points out, that though the author has shown that the lending channel in the Philippines has its significance in the monetary policy transmission, empirical studies about this has not been actively undertaken.

This paper segregated the banks according to the size of their assets, and then tested the relation of the movements of the ORRP with the loan supply of these banks.

The study finds that small banks are more sensitive to contractions in monetary policy rates than banks with bigger assets. Though the results are as expected, further studies can be made and more variables can be added to strengthen the evidence of the presence of these lending channels. Further studies can pursue the inclusion of finer types of deposits and securities as variables than can influence the supply of loans as some studies such as [6] included those variables. As policy rates shift upward, increase in time deposits and securities may be able to cushion the decline in loan supply for smaller banks.

Another area for research is the examination of the presence of the lending channel relative to the banks' capitalization with the use of the banks' capital leverage ratio which was not implemented in this paper because of data limitations. This is another bank characteristic that may influence the movements of loan supply in relation to policy rates. The use of capitalization to determine the degree of policy transmission through banks can illustrate the distributional effects of monetary policy. A bank's capitalization can be a gauge of its ability to increase needed deposits in case of shifts in policy rates.

The study covers only evidence on bank lending channel. Empirical studies can be done on providing evidence for the evidence of the borrowers' net worth channel in the Philippines. As an extension, this study can be supplemented to cover previous years to be able to accurately demonstrate the presence of the bank lending channel in the Philippines.

Finally, this paper shows that asset size can play an important factor in the formulation of monetary policy by its influence on the loan growth. Therefore, bank characteristic, particularly asset size, must be recognized and considered when examining and evaluating the distributional effects of monetary policy on loan supply and ultimately, its effects on the real economy. 
TABLE II (A): THE EFFECT OF MONETARy PoliCy ON THE GROWTH RATE OF TOTAL LOANS

\begin{tabular}{|c|c|c|c|c|c|c|}
\hline $\mathrm{B}=$ billion & $>\mathrm{P} 300 \mathrm{~B}$ & $\begin{array}{l}<\mathrm{P} 300 \mathrm{~B} \\
>\mathrm{P} 200 \mathrm{~B}\end{array}$ & $\begin{array}{l}<\mathrm{P} 200 \mathrm{~B} \\
>\mathrm{P} 100 \mathrm{~B}\end{array}$ & $\begin{array}{l}<\mathrm{P} 100 \mathrm{~B} \\
>\mathrm{P} 50 \mathrm{~B}\end{array}$ & $\begin{array}{l}<\mathrm{P} 50 \mathrm{~B} \\
>\mathrm{P} 25 \mathrm{~B}\end{array}$ & $<\mathrm{P} 25 \mathrm{~B}$ \\
\hline $\begin{array}{l}\text { Constant } \\
\text { t-stat }\end{array}$ & $\begin{array}{l}-0.0668 \\
(2.1895)\end{array}$ & $\begin{array}{l}-0.1122 \\
(2.8040)\end{array}$ & $\begin{array}{l}-0.0693 \\
(1.7297)\end{array}$ & $\begin{array}{c}0.0139 \\
(0.1851)\end{array}$ & $\begin{array}{l}-0.1027 \\
(0.6340)\end{array}$ & $\begin{array}{l}-0.6857 \\
(2.7872)\end{array}$ \\
\hline $\begin{array}{l}\mathrm{R} \\
\mathrm{t}-\mathrm{stat}\end{array}$ & $\begin{array}{l}-0.0061 \\
(0.5259)\end{array}$ & $\begin{array}{l}-0.0144 \\
(1.0466)\end{array}$ & $\begin{array}{l}-0.0144 \\
(1.0001)\end{array}$ & $\begin{array}{c}0.0125 \\
(0.4942)\end{array}$ & $\begin{array}{l}-0.0222 \\
(0.4031)\end{array}$ & $\begin{array}{c}-0.2492 \\
(3.0002)\end{array}$ \\
\hline $\begin{array}{l}\text { GDP growth } \\
\text { t-stat }\end{array}$ & $\begin{array}{c}0.5334 \\
(2.9511)\end{array}$ & $\begin{array}{c}0.2567 \\
(2.3914)\end{array}$ & $\begin{array}{c}0.2614 \\
(1.8722)\end{array}$ & $\begin{array}{c}0.0155 \\
(0.1025)\end{array}$ & $\begin{array}{c}0.0732 \\
(0.1744)\end{array}$ & $\begin{array}{l}-0.3414 \\
-0.5456\end{array}$ \\
\hline $\begin{array}{l}\text { Inflation } \\
\text { t-stat }\end{array}$ & $\begin{array}{c}2.1079 \\
(2.0066)\end{array}$ & $\begin{array}{c}1.9619 \\
(1.6794)\end{array}$ & $\begin{array}{c}2.4282 \\
(1.8457)\end{array}$ & $\begin{array}{l}-0.2404 \\
(0.1197)\end{array}$ & $\begin{array}{c}7.8550 \\
(1.6802)\end{array}$ & $\begin{array}{l}-4.2592 \\
(0.6325)\end{array}$ \\
\hline $\begin{array}{l}\text { Time trend } \\
\text { t-stat }\end{array}$ & $\begin{array}{c}0.0072 \\
(2.5079)\end{array}$ & $\begin{array}{c}0.0113 \\
(3.1773)\end{array}$ & $\begin{array}{c}0.0065 \\
(1.7891)\end{array}$ & $\begin{array}{l}-0.0003 \\
(0.0523)\end{array}$ & $\begin{array}{c}0.0022 \\
(0.1526)\end{array}$ & $\begin{array}{c}0.0634 \\
(2.8997)\end{array}$ \\
\hline $\begin{array}{l}\mathrm{AR}(1) \\
\text { t-stat }\end{array}$ & $\begin{array}{l}-0.5732 \\
(4.6630)\end{array}$ & $\begin{array}{l}-0.2355 \\
(1.8423)\end{array}$ & $\begin{array}{l}-0.3487 \\
(2.4618)\end{array}$ & $\begin{array}{l}-0.1012 \\
(0.7104)\end{array}$ & $\begin{array}{l}-0.2223 \\
(2.4138)\end{array}$ & $\begin{array}{c}-0.2416 \\
(1.9244)\end{array}$ \\
\hline${\operatorname{Adj~} \mathrm{R}^{2}}$ & 0.6372 & 0.2861 & 0.2340 & -0.0646 & 0.0375 & 0.1011 \\
\hline Durbin-Watson & 1.8723 & 1.6450 & 1.9031 & 1.9278 & 2.0127 & 1.9135 \\
\hline No. of banks & 4 & 6 & 4 & 5 & 10 & 6 \\
\hline
\end{tabular}

Notes: Inflation is the percent change of the GDP deflator

$\mathrm{AR}(1)$ is the coefficient from the serial correlation correction procedure computed using E-views 7

TABLE II (B): THE EFFECT OF MONETARY POLICY ON THE GROWTH RATE OF TOTAL LOANS

\begin{tabular}{|c|c|c|c|c|c|c|c|c|}
\hline & $\begin{array}{c}\text { Large } \\
\text { Total Assets }\end{array}$ & Deposits & Securities & Loans & $\begin{array}{c}\text { Large } 1 \\
\text { Total } \\
\text { Assets }\end{array}$ & Deposits & Securities & Loans \\
\hline Mean & 651,115 & 513,939 & 66,295 & 281,692 & 244,643 & 163,683 & 27,237 & 86,155 \\
\hline Maximum & $1,067,815$ & 837,008 & 104,632 & 635,123 & 339,992 & 246,808 & 41,731 & 142,714 \\
\hline Minimum & 369,858 & 285,397 & 25,960 & 110,894 & 160,274 & 69,903 & 6,969 & 43,601 \\
\hline Std. dev. & 154,509 & 124,252 & 16,696 & 114,415 & 40,206 & 38,627 & 9,901 & 19,618 \\
\hline Skewness & 0.64 & 0.52 & 0.02 & 1.21 & 0.28 & -0.05 & -0.90 & 0.16 \\
\hline \multirow[t]{2}{*}{ Observations } & 64 & 64 & 64 & 64 & 96 & 96 & 96 & 96 \\
\hline & Large 2 & & & & Medium 1 & & & \\
\hline Mean & 147,737 & 107,512 & 12,132 & 49,665 & 72,547 & 55,929 & 7,371 & 24,282 \\
\hline Median & 147,021 & 105,698 & 13,121 & 48,019 & 71,180 & 55,446 & 6,357 & 21,474 \\
\hline Maximum & 215,061 & 160,960 & 30,393 & 85,612 & 112,632 & 92,293 & 19,442 & 47,581 \\
\hline Minimum & 97,670 & 69,071 & 610 & 23,742 & 38,906 & 27,408 & 263 & 11,496 \\
\hline Std. dev. & 26,728 & 24,134 & 6,844 & 15,762 & 20,854 & 20,131 & 4,440 & 8,401 \\
\hline Skewness & 0.21 & 0.15 & 0.39 & 0.39 & 0.18 & 0.23 & 0.41 & 0.85 \\
\hline \multirow[t]{2}{*}{ Observations } & 64 & 64 & 64 & 64 & 80 & 80 & 80 & 80 \\
\hline & Medium 2 & & & & Small & & & \\
\hline Mean & 34,190 & 20,980 & 3,004 & 9,103 & 10,781 & 6,395 & 1,330 & 4,819 \\
\hline Median & 33,887 & 21,328 & 2,285 & 8,430 & 9,562 & 4,987 & 597 & 2,873 \\
\hline Maximum & 54,513 & 38,250 & 9,095 & 23,022 & 27,037 & 19,901 & 5,987 & 16,518 \\
\hline Minimum & 15,884 & 659 & 586 & 173 & 2,614 & 940 & 0 & 45 \\
\hline Std. dev. & 9,264 & 9,098 & 2,158 & 5,754 & 6,932 & 5,498 & 1,844 & 4,807 \\
\hline Skewness & 0.10 & -0.30 & 1.06 & 0.22 & 1.01 & 1.00 & 1.78 & 1.31 \\
\hline Kurtosis & 2.01 & 2.58 & 3.39 & 2.21 & 3.07 & 2.78 & 4.26 & 3.50 \\
\hline Observations & 160 & 160 & 160 & 160 & 95 & 95 & 95 & 95 \\
\hline
\end{tabular}

\section{REFERENCES}

[1] B. Bernanke and A. S. Blinder, "The federal funds rate and channels of monetary transmission," American Economic Review, vol. 82, pp. 901-22, 1992.

[2] A. K. Kashyap and J. C. Stein, "The impact of monetary policy on balance sheets," Carnegie-Rochester Conference Series on Public Policy, vol. 42, pp. 151-195, 1995.

[3] M. S. Islam and R. S. Rajan, "Bank lending channel of monetary policy transmission: India and the global financial crisis," International Journal of Economics and Business Research, vol. 3, no. 5, pp. 557-575, 2011.

[4] J. Tirole, The Theory of Corporate Finance. Princeton University Press, pp.471, 2006.

[5] S. Cecchetti, "Distinguishing theories of monetary transmission mechanism," Federal Reserve Bank of St. Louis Review, vol. 77, no. 6, pp. 83-97, 1995.

[6] R. Kishan and T. Opiela, "Bank size, bank capital and bank lending channel," Journal of Money and Credit and Banking, vol. 32, no. 1, pp. 121-141, 2000.
[7] B. Bernanke and M. Gertler, "Inside the black box:The credit channel of the monetary policy transmission," Journal of Economic Perspectives, vol. 9, no. 4, pp. 27-48, 1995.

[8] A. Coll, E. Torres, and E. Santander, "The bank lending channel in Venezuela: evidence from bank level data," Working paper, Banco Central de Venezuela Publications, vol. 67, 2005.

[9] D. Guinigundo, "Transmission mechanism of monetary policy in the Philippines," BIS Papers chapters in: Bank for International Settlements (ed.), Transmission mechanisms for monetary policy in emerging market economies, Bank for International Settlements, vol. 35, pp. 413-425, 2008.

[10] V. Fernandez, "Monetary policy and the banking sector in Chile," Emerging Markets Finance and Trade, vol. 41, no. 3, pp. 5-36, 2005.

[11] J. Peek and E. S. Rosengren, "Bank lending and the transmission of monetary policy,"New Economic Review, Federal Reserve Bank, pp. 3-11, November 1995.

[12] N. Apergis and E. Alevizopoulou, "Bank efficiency and the bank lending channel: evidence from a panel of European banks,"Global Business and Economics Anthology, vol. 11, pp. 30-43, 2011.

[13] C. S. Morris and G. H. Sellon Jr., "Bank lending channel and monetary policy: evidence on a credit channel," Economic Review, QI, pp. 59-75, 1995. 
[14] V. B. Bayangos, "Does the bank credit channel of monetary policy matter in the Philippines?" presented at the Third Annual Asian Research Network Workshop, Japan, 2010

[15] A. K. Kashyap and J. C. Stein, "What do a million observations on banks say about the transmission of monetary policy?" American Economic Review, vol. 90, no. 3, pp. 407-428, 2000

[16] M. Olivero, Y. Li, and B. Jeon, "Competition in banking and the lending channel: evidence from bank-level data in Asia and Latin America," Journal of Banking and Finance, vol. 35, pp. 560-571, 2011.

[17] S. F. Schnatter and S. Kauffman, "How do changes in monetary policy affect bank lending? An analysis of Austrian bank data," Journal of Applied Econometrics, vol. 21, pp. 275-305, 2006.

[18] R. Bischel and J. Perrez, "In quest of the bank lending channel: evidence for Switzerland using individual bank data," Swiss Journal of Economics and Statistics, vol. 141, no. 3, pp. 165-190, 2005.

[19] S. V. den Huevel, "The bank capital channel of monetary policy," Meeting papers, vol. 512, Society for Economic Dynamics. 2006.

[20] G. J. De Bondt, "Credit channels in Europe: bank-level panel data analyses," Research memorandum WO\&E $\mathrm{nr}$ 543/9813, De Nederlandsche Bank, Amsterdam, 1998.

[21] I. Hernando and J. Martinez-Pages, "Is there bank lending channel of monetary policy in Spain?" Working paper, European Central Bank, no. 99,2011

[22] L. Liu, "Monetary policy, bank size and bank lending: evidence from Australia," MPRA Paper 37489, University Library of Munich, Germany, 2012.

[23] B. Bernanke and I. Milhov, "Measuring monetary policy," Working paper, National Bureau of Economic Research, no. 5145, 1995.
[24] P. K. Brooks, "The bank lending channel of monetary transmission: does it work in Turkey?" Working paper, $I M F$, no. 07/272, 2007.

[25] S. Becketti and C. Morris, "Are bank loans still special?" Economic Review, Federal Reserve Bank of Kansas City, vol. 3, pp. 71-84, 1992

[26] B. M. Friedman and N. Kuttner, "Economic activity and the short-term credit markets: an analysis of prices and quantities," Brookings Papers on Economic Activity, vol. 2, pp.193-283, 1993.

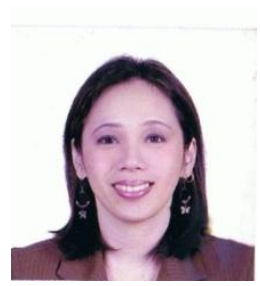

Maria Josefina Angelica C. Aban is presently a $\mathrm{Ph} . \mathrm{D}$. student at the University of the Philippines, Diliman, Quezon City, majoring in business administration. She received her Masters degree in business administration, with honors, from the Ateneo de Manila Graduate School of Business in 2004. She graduated in 1987 with a Bachelor's degree major in mathematics from Saint Pau College, Quezon City, Philippines. Prior to being a lecturer at the San Beda College, Manila, Philippines, she was a senior manager at the Bank of the Philippine Islands until 2008. Her employment history includes Far East Bank and Trust Co. as Branch Manager and Merrill Lynch Philippines Inc. as operations staff. Her paper entitled, Evidence of bank lending channel in the Philippines was presented at the 2012 International Conference on Economics, Business and Management in Kuala Lumpur, Malaysia, sponsored by the International Economics Development and Research Center. Her current researches include Market power and Competition of banks in the Philippines and Adoption of internet banking in the Philippines. 